\title{
Apropos of the postponement of the 26th International Conference of the Red Cross and Red Crescent
}

"Man is destined to think and
act amidst uncertainty and the
unforeseen."

(Edgar Morin)

The postponement of the 26th International Conference of the Red Cross and Red Crescent, which was to have taken place in Budapest, has already given rise to a number of analyses, and explanations have been furnished to those who were to have taken part.

In this issue of the International Review of the Red Cross we have the opportunity to encourage further reflection, within the Movement and with the governments, on the lessons to be learned from the Budapest experience, and to report on the important meetings held by the Movement's components in the Hungarian capital.

The Council of Delegates in particular adapted immediately to the change in circumstances. The prolongation of the session and the lively and constructive discussions that ensued demonstrated the importance of enhancing the role of this forum. This was without doubt one of the favourable consequences of the postponement.

Some of the items on the Conference agenda were the subject of interesting debate among the Movement's members, but it was nevertheless apparent that this was no substitute for dialogue with the governments. Of course, opinions may vary as to the importance of that dialogue. This is why we should first examine once again why 
the International Conference is held, ${ }^{1}$ and only then reflect on the conditions to be met before starting actual preparations.

\section{Why hold International Conferences of the Red Cross and Red Crescent?}

The International Conference affords a unique opportunity to focus the attention of States on the victims the Movement serves.

Of course, dialogue with the States is not limited to those few days every four years. The National Societies usually have frequent contact with their respective governments, and the ICRC is constantly in touch with the governments of the countries in which it is carrying out humanitarian activities, with any other governments involved and with those financing its operations. It is also in touch with almost every government in the world in connection with the promotion and dissemination of humanitarian law. The major difference between those bilateral contacts and the Conference, however, is that the latter makes decisions which affect the entire international community. Richard Perruchoud has written a thesis on the significance of Conference resolutions, ${ }^{2}$ and it is not my intention to summarize what he says here. What is clear - and several diplomats have confirmed it is that the Conference obliges the governments to state publicly where they stand on the general or specific problems put before them. Any move to develop humanitarian law or to strengthen the instruments for its application must perforce be dealt with by the International Conference. It is also at International Conferences that the international community makes commitments on National Society matters, in particular the development of the weakest among them.

${ }^{1}$ In this respect, it is useful to turn back to what was written after the 25th International Conference, in particular in the following publications: de Tscharner, Bénédicte, «La Croix-Rouge internationale après la XXVe Conférence internationale de la Croix-Rouge», Hispo, Booklet 9, Association d'histoire et de science politique, Bern, pp. 29-46; Moreillon, Jacques, «Suspension of the government delegation of the Republic of South Africa at the Twenty-fifth International Conference of the Red Cross (Geneva, 1986) - Different perceptions of the same event», International Review of the Red Cross, No. 257, March-April 1987, pp. 133-151; Sandoz, Yves, «Analyse juridique de la décision de suspendre la délégation gouvernementale sud-africaine de la XXVe Conférence internationale de la Croix-Rouge», Annuaire français de Droit International, vol. XXXII, 1986, pp. 591-602.

${ }^{2}$ Perruchoud, Richard, Les Résolutions des Conférences internationales de la Croix-Rouge, Henry Dunant Institute, Geneva, 1979, 470 pp. 
The postponement of an International Conference has no immediate tangible effect, but were we to abandon such conferences altogether, in the long run the Movement would become indistinguishable from the countless other humanitarian organizations. Moreover, the ICRC would probably lose the special status as custodian of international humanitarian law that it has enjoyed since the origins of the law.

That in turn would undermine the Movement's international position, and humanitarian law would inevitably fall prey to increasing politicization. And all this would obviously be to the detriment of the victims who are the Movement's primary concern. So the stakes are high.

We should bear these matters in mind when examining the conditions which must be met before preparations for an International Conference can begin.

\section{Prerequisites to be met}

Several National Societies were traumatized by the events which led to the suspension of the South African government delegation from the 25th International Conference in Geneva in 1986. Indeed, the political debate which took place at the Conference was seen by the general public in many countries as a sign that the Movement itself was becoming politicized.

Those reactions, and the incomprehension of many volunteers, gave rise to feelings of unease on the part of numerous National Societies. This certainly influenced the Standing Commission's decision to postpone the 26th Conference for fear that a similar dispute would break out on the form of Palestinian participation.

In taking its decision, the Standing Commission avoided the risk of political discussion but created another problem, this time essentially with the States. Governments are accustomed to that kind of political debate, and it would never even occur to them to put off a longplanned meeting for such a reason. The governments were involved in the preparations for the Budapest Conference, in some cases very actively, and the decision to postpone it took them by surprise.

On the basis of their reactions we can say that the governments understood the Movement's special sensitivity in this area and therefore why the decision was made. But they will not countenance a repeat performance of what happened in Budapest, or even run the risk of such an occurrence. 
Government administrations are overburdened as it is and take a poor view of being made to work for nothing. If we want an International Conference, we must make a clear commitment that we will go ahead with it no matter what happens.

In other words, we must find a way of protecting the Movement from the adverse impact of stormy debates like the one that took place in Geneva, and we must give the governments our word that the experience of Budapest will not be repeated.

\section{How to avoid a repetition of what happened at the 1986 Geneva Conference?}

One idea which has been mooted is that the date of the Conference should be set only once all problems of participation have been resolved. This is obviously unrealistic, and would in fact amount to abandoning the Conference altogether. The pace of events in the modern world is such that no definitive solution for this type of problem could be found one or two years in advance, the minimum amount of time required to organize and make practical arrangements for a conference of this scope.

In the article from which the introductory quote is taken, Edgar Morin makes a very pertinent statement: "(...) effective action always involves a risk, which calls for a strategy, i.e., the drawing up of a scenario which can be adapted to changing circumstances". ${ }^{3}$

If the Movement wants the International Conference - and we have clearly expressed our conviction that the Conference is necessary - then it must be prepared to take the risk involved. We must be courageous, but we need not be foolhardy. We must have a scenario, a plan which puts all the odds on our side. This means that we first have to identify the risk, to know exactly what it is we want to avoid.

There are in fact two dangers: first that the Movement's components will be forced to debate an essentially political matter, and secondly that such a debate will give the general public the impression that the Movement is becoming politicized.

\footnotetext{
3 Morin, Edgar, Le Monde, 26 November 1991, p. 2.
} 


\section{Keeping the Movement out of political controversy}

Political argument represents a real threat to the principle of neutrality, and is a potential danger for the principle of independence in a situation where government and National Society delegations are sitting side by side.

Although there can never be a guarantee that no political debate will take place, everything possible must be done to make sure that questions relating to participation are negotiated and settled by the States before the Conference. Intensive consultations with the States did take place in the months leading up to the Budapest Conference, and in fact acceptable solutions had been found to almost all the many problems concerning participation. Only the negotiations on the form of Palestinian participation - admittedly a particularly thorny issue ended in failure.

Is there a better way to handle this kind of issue? This is the question on which our discussions with the States must focus. There are several interesting possibilities. For example, a group of States could be asked to examine such matters beforehand with a view to proposing solutions to the Conference, or to convening a preparatory conference, participation in which could be limited to the States. In addition, ad hoc agreements on the procedure to be followed during the Conference in respect of a specific problem which had not been solved beforehand would probably make it easier to settle any such issue rapidly and without contention.

Specific procedures will in any case have to be set up in preparation for the 26th Conference, but the possibility of structural change involving amendment of the Movement's Statutes should also be considered. The Statutes would have to be amended if the Standing Commission were to be enlarged to include State representatives, or a Commission of States created to deal with problems connected with the participation of States party to the Geneva Conventions, or a preparatory conference convened. We must naturally think carefully before embarking on amendments to the Statutes, as this entails a vast amount of preparatory work and would have to be accepted by a twothirds majority of the members of the Conference present and voting. ${ }^{4}$ It would be ill-advised, however, to rule out such a possibility from the outset.

${ }^{4}$ See Statutes of the International Red Cross and Red Crescent Movement, Art. 20. 


\section{Protecting the Movement's image}

As concerns the second danger, i.e., that the public would be left with the image of a politicized Movement, several proposals merit consideration. First, the governments' role at the Conference would have to be clearly explained, and this would obviously be much easier if the governments agreed to assume a higher profile in solving problems of participation, as mentioned above. The Movement could also decide in advance not to take part in a vote on participation, thereby clearly demonstrating that it remains outside politics. In fact, the ICRC's representatives in Budapest, who were not in favour of postponing the Conference, suggested this course of action to the Standing Commission.

Here again, apart from the measures to be envisaged immediately, it would be useful to consider, with the reservations expressed above, whether or not amendment of the Statutes would improve the public's perception of International Conferences in the long term. In this respect, one member of the Standing Commission drew attention to the somewhat equivocal nature of the Conference's name. He pointed out that the name contained no indication of government participation, but suggested that the Conference was an internal meeting of the Movement's components. ${ }^{5}$ Going even further, the same member criticized the definition of the Conference as the Movement's "supreme deliberative body", 6 because it gives the impression that the States party to the Geneva Conventions are an integral part of the Movement. Although they were discussed at length when the revised Statutes were adopted in 1986, these questions call for further study.

\section{Conclusion}

The Movement, international humanitarian law and, above all, the victims which both seek to assist stand to lose a great deal if there are no more International Conferences. It is therefore vital that everything possible be done to preserve this very special link and opportunity for dialogue between the Movement's components and the States party to the Geneva Conventions.

5 See Hantos, János, "The Fundamental Principles are vital to the unity of the International Red Cross and Red Crescent Movement», International Review of the Red Cross, No. 275, March-April 1990, pp. 86-94, esp. at p. 93.

6 Article 8 of the Movement's Statutes. 
The wide range of topics which were to have been dealt with in Budapest, the far-reaching changes which have taken place on the international scene since the 1986 Conference, and ongoing discussions with regard to coordination of humanitarian assistance, in particular within the UN and the European Community, make the holding of the 26th International Conference a matter of urgency. Taking into account the time needed to prepare for such a gathering, a reasonable target date would be 1993 .

It should be possible, through extensive dialogue with the States, to devise procedures giving them greater responsibility for solving problems of participation, which are essentially political in nature.

The Red Cross and Red Crescent Movement must take a firm position and show the States that it is determined to hold the Conference come what may. By so doing, it will demonstrate that it is ready to face up to the realities of our time. On the other hand, showing itself fearful of confronting the governments at International Conferences would project a feeble image. A strong National Society, one whose roots run deep and whose energy and work are appreciated by the public, will be better able to explain the purpose of International Conferences and the problems inherent in any dialogue with the States.

Thus, in demonstrating its attachment to the International Conference, the Movement must also reaffirm its intention to become stronger itself, so as to meet the challenges of today's world not only on the international but also on the national level. Street children, child prostitution, refugee problems, the poverty affecting broad sectors of the population even in rich countries: the potential for National Society endeavour is enormous. The best way for the Societies to strengthen their bonds with the people, who must feel that the Red Cross or the Red Crescent share their concerns, is to tackle these problems with compassion and enthusiasm, always seeking new spheres of activity. The study on the Movement's future decided on by the Council of Delegates will certainly produce constructive ideas as to the best means of meeting these challenges.

Any shock-waves generated at International Conferences will be much more easily absorbed by a strong Movement. By taking the conscious decision to make preparations for the 26th International Conference, the Movement will display renewed self-confidence and resolution.

There is nevertheless a slight possibility that a majority of the Movement's members will decide to back away from the issue and give up the International Conference in its present form. In that event, the ICRC would be obliged to consider other types of dialogue with 
the governments. But it would be reluctant to do so, for it is convinced that the International Conference in its present tried-andtested form, perhaps with some minor changes, is the best solution.

We are looking forward to the 26th International Conference!

\section{Yves Sandoz}

Member of the Executive Board

Director

Principles, Law and Relations

with the Movement

ICRC 